\title{
$\mathrm{Ni}-\mathrm{Mn}$ 전착층의 기계적 성질에 미치는 공정조건의 영향
}

\author{
신 지 웅·양 승 기·황 운 석 ${ }^{\dagger}$ \\ 인하대학교 신소재공학부, 인천시 남구 인하로 100
}

(2014년 6월 20일 접수, 2014년 6월 27일 수정, 2014년 6월 27일 채택)

\section{Influences of Electrodeposition Variables on Mechanical Properties of Ni-Mn Electrodepositions}

\author{
Ji-wung Shin, Seung-gi Yang, and Woon-suk Hwang ${ }^{\dagger}$ \\ Department of Materials Science and Engineering, Inha University 100 Inharo, Namgu, Inchon, 402-751, Korea
} (Received June 20, 2014; Revised June 27, 2014; Accepted June 27, 2014)

\begin{abstract}
Nickel electrodeposition from sulfamate bath has several benefits such as low internal stress, high current density and good ductility. In nickel deposited layers, sulfur induces high temperature embrittlement, as Ni-S compound has a low melting temperature. To overcome high temperature embrittlement problem, adding manganese is one of the good methods. Manganese makes Mn-S compound having a high melting temperature above $1500^{\circ} \mathrm{C}$.

In this work, the mechanical properties of Ni-Mn deposited layers were investigated by using various process variables such as concentration of $\mathrm{Mn}\left(\mathrm{NH}_{2} \mathrm{SO}_{3}\right)_{2}$, current density, and bath temperature. As the Mn content of electrodeposited layers was increased, internal stress and hardness were increased. By increasing current density, internal stress increased, but hardness decreased. With increasing the bath temperature from 55 to $70^{\circ} \mathrm{C}$, internal stress of $\mathrm{Ni}$ deposit layers decreased, but hardness didn't change by bath temperature. It was likely that eutectoid manganese led to lattice deformation, and the lattice deformation increased hardness and internal stress in Ni-Mn layers. Increasing current density and decreasing bath temperature would increase a mount of $\mathrm{H}_{2}$ absorption, which was a cause for the rise of internal stress.
\end{abstract}

Keywords : Ni-Mn, electrodeposition, internal stress, hardness, sulfamate bath

\section{1. 서 론}

$\mathrm{Ni}$ 전착층은 내식성과 기계적 성질이 우수하여 산업의 여러 분야에서 응용되고 있으며, 기계적 성질을 향상시키기 위해 다양한 연구가 이루어지고 있다. ${ }^{122} \mathrm{Ni}$ 설파메이트욕 은 1930년 Piontelli와 Cambri에 의해 고안된 것으로 알려 져 있으며, 1950년대부터 상업적으로 사용하기 시작하였 다. 설파메이트욕은 와트욕에 비해 내부응력이 낮고, 연성 이 우수한 특성을 가지고 있으며, 고전류밀도에서 합금전착 이 용이하다. 또한 첨가제와 공정조건에 따라 기계적 성질 을 광범위하게 조절할 수 있으며, 욕 조성이 간단하여 관리 와 유지가 용이하다는 장점이 있다. ${ }^{3)}$

$\mathrm{Ni}$ 전착층에서 $\mathrm{S}$ 는 $\mathrm{Ni}$ 와 화합물을 형성한다. $\mathrm{Ni}-\mathrm{S}$ 화합
물은 융점이 약 $910^{\circ} \mathrm{C}$ 로서 $\mathrm{Ni}$ 의 융점 $1455{ }^{\circ} \mathrm{C}$ 에 비하여 융점이 낮기 때문에 고온 환경에서 사용시 취성을 나타낸다. 따라서 $\mathrm{Ni}$ 전착에서 $\mathrm{Ni}$ 보다 $\mathrm{S}$ 와 친화성이 좋은 $\mathrm{Mn}$ 을 첨가 하여 융점이 $1500^{\circ} \mathrm{C}$ 이상인 $\mathrm{Mn}-\mathrm{S}$ 화합물을 형성하게 하면 $\mathrm{S}$ 에 의한 고온취성을 방지할 수 있을 것으로 생각된다. ${ }^{4)}$

본 연구에서는 $\mathrm{Ni}$ 설파메이트욕에서 $\mathrm{Mn}$ 공급원인 $\mathrm{Mn}$ $\left(\mathrm{SO}_{3} \mathrm{NH}_{2}\right)_{2} \cdot 4 \mathrm{H}_{2} \mathrm{O}$ 의 첨가량, 전류밀도, 전착온도 등의 공 정변수를 달리하여 $\mathrm{Ni}-\mathrm{Mn}$ 전착층을 형성하였다. 그리고 공정변수에 따른 전착층의 경도, 내부응력, $\mathrm{Mn}$ 및 $\mathrm{S}$ 공석량 등을 분석하였고, 이들의 상관관계를 검토하였다. 향후 본 연구를 바탕으로 $\mathrm{Ni}$ 전착층에서 고온취성에 미치는 $\mathrm{S}$ 의 영 향과 $\mathrm{Mn}$ 의 효과에 대하여 분석할 예정이다.

\footnotetext{
${ }^{\dagger}$ Corresponding author: wnshwang@inha.ac.kr
} 


\section{2. 실험방법}

\section{$2.1 \mathrm{Ni}$ 전착액}

본 연구에서 사용한 전착액은 $\mathrm{Ni}$ 의 공급원으로서 $\mathrm{Ni}$ $\left(\mathrm{SO}_{3} \mathrm{NH}_{2}\right)_{2} \cdot 4 \mathrm{H}_{2} \mathrm{O}$ 와 $\mathrm{NiCl}_{2} \cdot 6 \mathrm{H}_{2} \mathrm{O}$ 를 사용하였고, $\mathrm{Mn}$ 공 급원으로서 $\mathrm{Mn}\left(\mathrm{SO}_{3} \mathrm{NH}_{2}\right)_{2} \cdot 4 \mathrm{H}_{2} \mathrm{O}$ 를 사용하였다. 그리고 Buffer로 $\mathrm{H}_{3} \mathrm{BO}_{3}$ 를 첨가하여 전착액을 건욕하였다.

$\mathrm{EP}$ 급 시약을 사용하였으며, 정량을 이온교환수에 용해하 여 제조하였다. $\mathrm{pH}$ 조정제로서 $\mathrm{HOSO}_{2} \mathrm{NH}_{2}$ 를 이온교환수 와 $1: 1$ 로 희석시킨 용액을 사용하여 $\mathrm{pH} 4.0$ 으로 조절하였 다.

\section{2 시험편 제작}

순도 $99.9 \%$ 의 $\mathrm{Cu}$ 판재를 사용하여 기초시험용 시험편을 제작하였다. $\mathrm{Cu}$ 판재를 $20 \mathrm{~mm} \times 20 \mathrm{~mm}$ 가 되도록 절단한 후 호마이카액으로 마운팅 후 전착이 되지 않는 후면에 도선

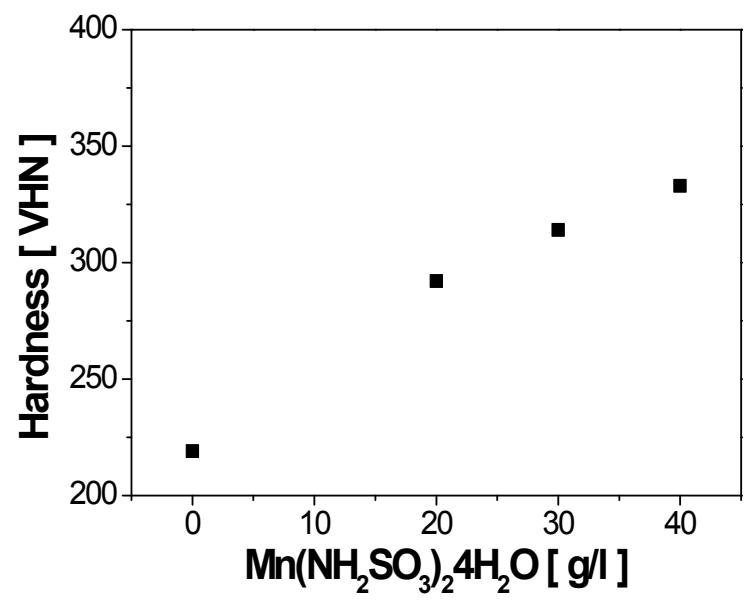

Fig. 1. Effect of $\mathrm{Mn}\left(\mathrm{NH}_{2} \mathrm{SO}_{3}\right)_{2} \cdot 4 \mathrm{H}_{2} \mathrm{O}$ addition on the hardness of $\mathrm{Ni}-\mathrm{Mn}$ electrodepoits.



Fig. 2. Effect of $\mathrm{Mn}\left(\mathrm{NH}_{2} \mathrm{SO}_{3}\right)_{2} \cdot 4 \mathrm{H}_{2} \mathrm{O}$ addition on the internal stress of Ni-Mn electrodepoits.
을 연결하고 실리콘으로 실링처리를 하여 전기적으로 접촉 이 가능하게 하였다. 시편의 전처리로서 $\mathrm{SiC}$ 에머리지로 $\# 2,000$ 까지 연마를 하였다. 이 시험편을 알카리탈지액에 5 분간 초음파 탈지를 하고 수세한 다음, 아세톤에 3 분간 침지하여 표면층의 불순물들을 제거 후 수세한 다음 전착을 수행하였다.

\section{3 전해조}

$1 \mathrm{~L}$ 크기의 원형의 파이렉스 전해조를 사용하였다. anode 와 cathode의 전극간 거리를 $40 \mathrm{~mm}$ 로 유지하였고, anode 로는 $50 \mathrm{~mm} \times 40 \mathrm{~mm}$ 크기의 $\mathrm{Ni}$ 판재를 사용하였다.

\section{4 경도 측정}

전착층의 경도를 측정하기 위하여 일본 Mitutoyo사의 MVK-E3 Microvikers hardness tester를 이용하여 하 중 $1.0 \mathrm{~N}$ 으로 5 초간 수행 후, Indentor 자국을 측정하여 경도치로 환산하였다. 10 회 측정하여 최고값과 최저값을 제외한 나머지 8회 측정치의 평균한 값을 경도치로 채택하 였다.

\section{5 내부응력 측정}

Strip type deposit stress analyzer를 이용하여 전착층 의 내부응력을 측정하였다. 내부응력 시험편은 2 개의 다리 가 달린 형태의 베릴륨 동 합금재로서 2 개의 다리는 서로 반대방향의 편면만 전착이 이루어지도록 하였다. 전착층의 두께와 응력시편의 벌어진 거리를 측정하여 내부응력으로 환산하였다.

\section{3. 연구결과 및 고찰}

\subsection{Mn( $\left(\mathrm{NH}_{2} \mathrm{SO}_{3}\right)_{2}$ 첨가량에 따른 전착층의 기계적 성질변화}

$\mathrm{Mn}$ 공급원인 $\mathrm{Mn}\left(\mathrm{NH}_{2} \mathrm{SO}_{3}\right)_{2}$ 의 농도 변화가 $\mathrm{Ni}-\mathrm{Mn}$ 전착 층에 미치는 영향을 분석하였다. 전착액 온도 $60^{\circ} \mathrm{C}$, 전류밀 도 $5 \mathrm{~A} / \mathrm{dm}^{2}, \mathrm{pH} 4.0$ 조건에서, $\mathrm{Mn}\left(\mathrm{NH}_{2} \mathrm{SO}_{3}\right)_{2}$ 의 농도를 0 40g/l 범위에서 변화시키며 전착층을 형성하였다.

농도변화에 따른 $\mathrm{Mi}-\mathrm{Mn}$ 전착층의 경도와 내부응력 측정 결과를 각각 Fig. 1과 Fig. 2에 나타내었다. $\mathrm{Mn}\left(\mathrm{NH}_{2} \mathrm{SO}_{3}\right)_{2}$ 의 첨가량이 증가할수록 전착층의 경도 및 내부응력은 증가 하는 결과가 얻어졌다. 그리고 전착층 중의 $\mathrm{Mn}$ 과 $\mathrm{S}$ 의 공석 량을 각각 Fig. 3과 Fig. 4에 나타내었다. $\mathrm{Mn}\left(\mathrm{NH}_{2} \mathrm{SO}_{3}\right)_{2}$ 를 첨가하지 않은 경우 전착층에서 $\mathrm{Mn}$ 은 검출되지 않았고 $\mathrm{S}$ 는 $748 \mathrm{ppm}$ 으로 나타났다. 첨가량 $20 \mathrm{~g} / \mathrm{l}, 30 \mathrm{~g} / \mathrm{l}, 40 \mathrm{~g} / \mathrm{l}$ 조건에 서 $\mathrm{Mn}$ 의 공석량은 각각 $2787 \mathrm{ppm}, 3327 \mathrm{ppm}, 3509 \mathrm{ppm}$ 으 로 분석되었으며, $\mathrm{Mn}$ 공석량은 $\mathrm{Mn}\left(\mathrm{NH}_{2} \mathrm{SO}_{3}\right)_{2}$ 첨가량에 따라 증가하였다. S의 공석량은 각각 $814 \mathrm{ppm}, 851 \mathrm{ppm}, 909 \mathrm{ppm}$ 으로 $\mathrm{Mn}\left(\mathrm{NH}_{2} \mathrm{SO}_{3}\right)_{2}$ 첨가량에 따라 소폭 증가하였다. 


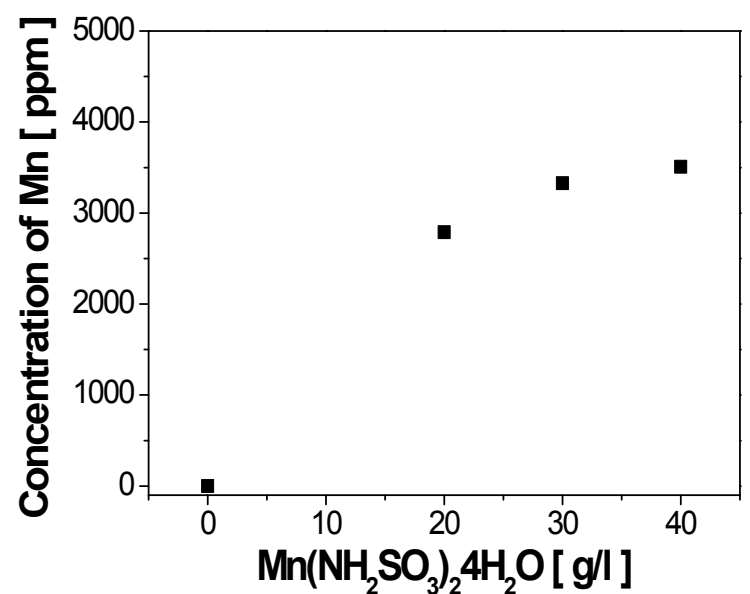

Fig. 3. Effect of $\mathrm{Mn}\left(\mathrm{NH}_{2} \mathrm{SO}_{3}\right)_{2} \cdot 4 \mathrm{H}_{2} \mathrm{O}$ addition on the $\mathrm{Mn}$ concentration of Ni-Mn electrodepoits.

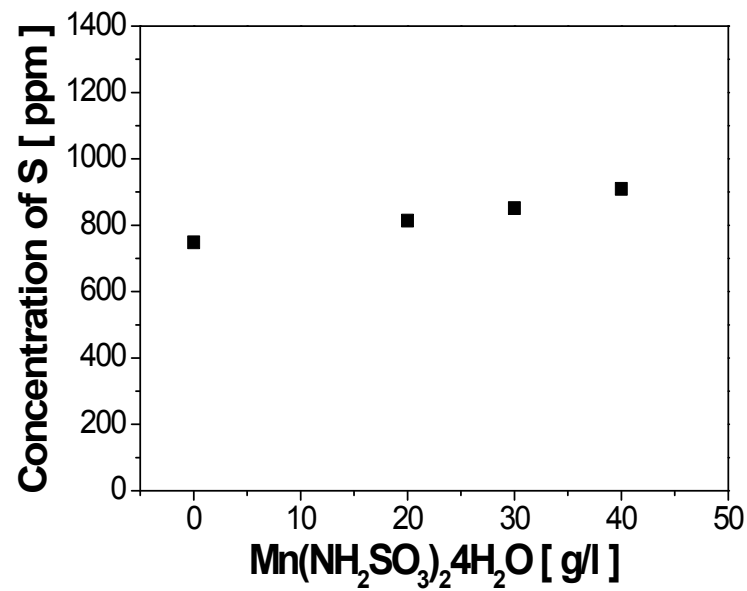

Fig. 4. Effect of $\mathrm{Mn}\left(\mathrm{NH}_{2} \mathrm{SO}_{3}\right)_{2} \cdot 4 \mathrm{H}_{2} \mathrm{O}$ addition on the $\mathrm{S}$ concentration of Ni-Mn electrodepoits.

Fig. 5에 $\mathrm{Mn}$ 공석량과 전착층 경도 그리고 내부응력의 상관관계를 나타내었다. $\mathrm{Mn}$ 의 공석량이 증가할수록 전착 층의 경도는 급격히 상승하는 결과를 보이고 있다. 그리고 Fig. 4에서의 결과를 보면 S의 공석량이 크게 변화하지 않 은 것으로부터 경도 증가의 원인은 $\mathrm{Mn}$ 의 공석량에 의존하 고 있는 것을 알 수 있다. 이는 $\mathrm{Ni}-\mathrm{Mn}$ 전착이 $\mathrm{Ni}$ 단상으로 존재하는 것으로부터 첨가된 $\mathrm{Mn}$ 이 $\mathrm{Ni}$ 원자를 치환하거나 공극사이로 침입하여 격자상수를 변형시키고, 변형된 격자 가 전위 등의 이동을 방해하여 경도가 증가한 것으로 생각된 다. ${ }^{5)}$ Fig. 5에 나타낸 $\mathrm{Mn}$ 공석량과 내부응력의 관계를 보 면, 전착층의 $\mathrm{Mn}$ 의 함량이 상승할수록 내부응력도 급격히 증가하였다. 전착층의 내부응력은 소지금속과 전착금속의 격자상수 차이에 의한 발생, 불순물의 유입에 의한 발생, 결정 성장시 발생하는 공공, 전위, 쌍정 등의 영향, 수소환원 반응이 수반되는 경우 수소원자의 확산에 의한 격자팽창 등의 이유로 발생하는 것으로 여겨진다, ${ }^{6)}$ 경도의 경우와

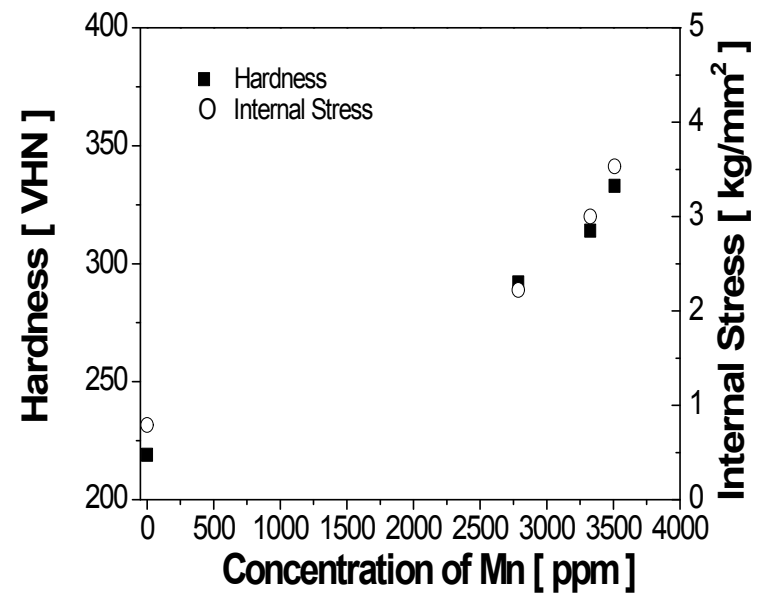

Fig. 5. Effect of Mn concentration on the hardness and the internal stress of Ni-Mn electrodepoits.

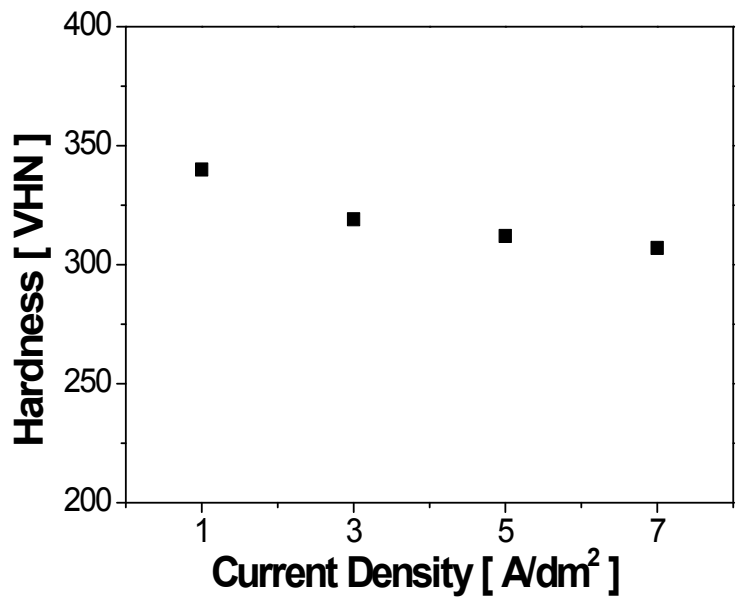

Fig. 6. Effect of current density on the hardness of Ni-Mn electrodepoits.

같이 공석된 $\mathrm{Mn}$ 이 증가할수록 $\mathrm{Ni}$ 전착층의 격자상수를 변 화시키고, 그 결과 내부응력이 증가한 것으로 판단된다.

\section{2 전류밀도에 따른 전착층의 기계적 성질변화}

전류밀도가 전착층의 기계적 성질에 미치는 영향을 분석 하기 위하여 전류밀도 $1 \sim 7 \mathrm{~A} / \mathrm{dm}^{2}$ 범위에서 변화시키며 전 착층을 형성하였다. 전류밀도 변화에 따른 전착층의 경도변 화를 Fig. 6에, 내부응력 변화를 Fig. 7에 각각 나타내었다.

전류밀도가 증가함에 따라 전착층의 경도는 약간 감소하 는 경향을 나타내었으나, 본 연구의 범위에서는 경도는 전 류밀도변화에 거의 의존하지 않았다.

전류밀도가 증가할 때 전착층의 내부응력은 상승하였다. 전류밀도가 증가하면 cathode에서 반응속도가 상승하게 되며, 수소환원반응 속도도 함께 증가한다. 수소환원반응 속도의 증가에 따라 전착층에 수소흡착이 증가하며, 전착층 내부에서 수소원자의 확산에 의한 격자 팽창이 내부응력 증가에 관여하고 있는 것으로 판단된다. 


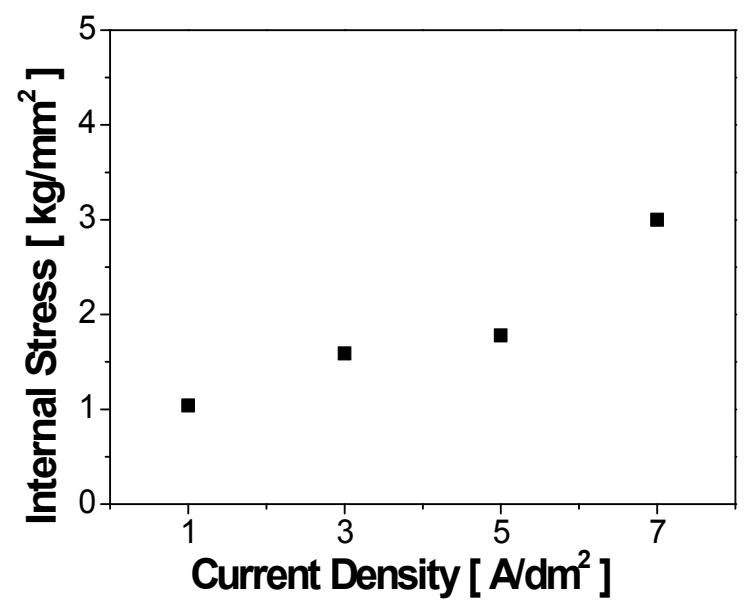

Fig. 7. Effect of current density on the internal stress of Ni-Mn electrodepoits.

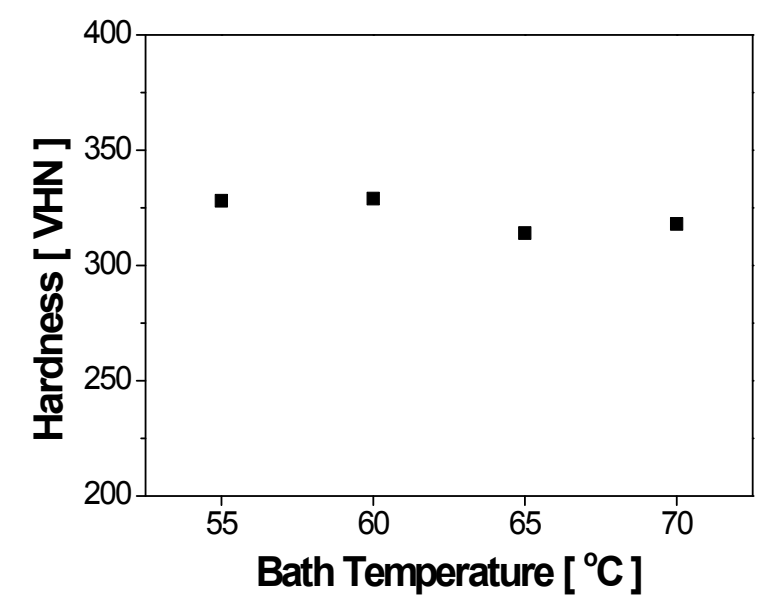

Fig. 8. Effect of bath temperature on the hardness of Ni-Mn electrodepoits.

\section{3 전착 온도에 따른 전착층의 기계적 성질변화}

전착 온도가 전착층에 미치는 영향을 검토하기 위하여 전착액 온도를 각각 $55^{\circ} \mathrm{C}, 60^{\circ} \mathrm{C}, 65^{\circ} \mathrm{C}, 70^{\circ} \mathrm{C}$ 로 변화시켜가 며 전착을 수행하였다. Fig. 8은 전착액 온도에 따른 전착층 의 경도를 나타낸 것으로 온도에 따라 경도는 큰 변화를 보이지 않았다.

Fig. 9는 전착액 온도에 따른 내부응력을 측정한 결과이 다. 온도가 상승할수록 전착층의 내부응력은 감소하였다. $\mathrm{SeO}$ 등 ()은 전착액 온도가 상승함에 따라 농도분극과 표면 확산이 감소하여 cathode쪽으로 이온공급이 원활해지며, 핵생성 및 성장을 위한 활성화에너지 이상의 활성화이온의 수가 증가하는 것으로 분석 하였으며, cathode에서 수소흡 착이 감소하는 것을 확인하였다. 그리고 Dini등8) 의 연구에 서도 $\mathrm{Ni}$ 전착시 전착액 온도가 증가하면 전착층 내부의 수 소를 비롯한 가스함량이 감소하는 것으로 보고하고 있다. 이와 같은 결과로부터 판단할 때, 전착욕 온도의 상승은 수

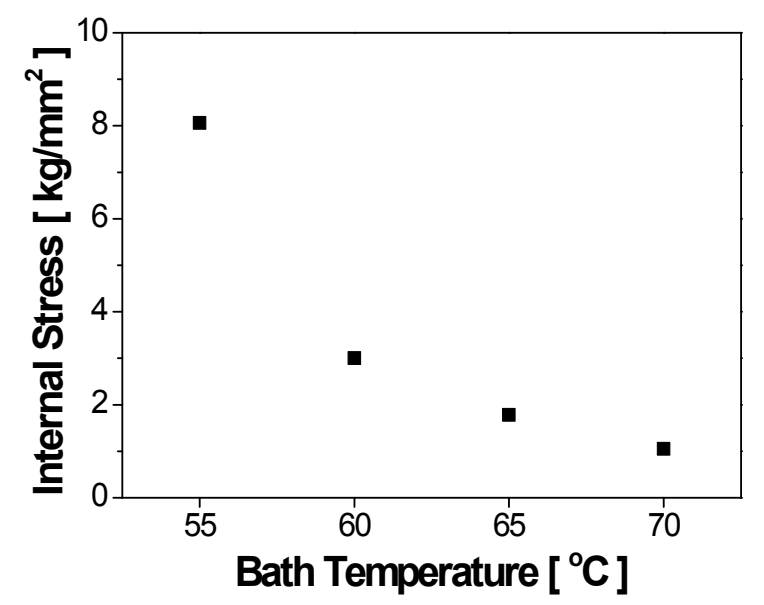

Fig. 9. Effect of bath temperature on the internal stress of Ni-Mn electrodepoits.

소환원반응을 저하시키고, 전착층 내부의 수소흡착을 감소 시키기 때문에 내부응력이 감소하는 것으로 생각된다.

\section{4 기계적 성질에 미치는 공정조건의 영향}

본 연구에서 전착층의 경도는 $\mathrm{Mn}$ 공급원인 $\mathrm{Mn}\left(\mathrm{NH}_{2} \mathrm{SO}_{3}\right)_{2}$ 의 첨가량에 따라 증가하였으며, 전류밀도와 전착온도의 변 화에 따라서는 크게 변하지 않았다. $\mathrm{Mn}\left(\mathrm{NH}_{2} \mathrm{SO}_{3}\right)_{2}$ 첨가량에 따라 전착층에 $\mathrm{Mn}$ 공석량이 크게 증가하였으며, 공석된 $\mathrm{Mn}$ 이 격자변형을 유발하여 경도를 증가시킨 것으로 생각된다. 내부응력은 공정조건의 변화에 따라 큰 변화를 보였다. $\mathrm{Mn}\left(\mathrm{NH}_{2} \mathrm{SO}_{3}\right)_{2}$ 의 첨가량에 따라 $\mathrm{Mn}$ 공석량이 증가하였으 며, 공석된 $\mathrm{Mn}$ 에 의한 격자변형으로 내부응력이 증가한 것 으로 생각된다. 또한 내부응력은 전류밀도의 증가에 따라 증가하였으며, 전착온도의 증가에 따라서는 감소하였다. 전 류밀도 및 전착온도 변화에 따라 내부응력이 변하는 이유를 전착층 내부의 수소에 의한 것으로 생각된다. 전류밀도가 증가할수록 cathode에서의 환원속도가 증가하기 때문에 수소환원반응 속도도 증가하는 것으로 생각되며, 전착온도 가 증가할 때 농도 분극 및 표면확산 등의 감소와 활성화 이온수의 증가로 $\mathrm{Ni}$ 의 환원반응속도는 증가하고 수소환원 반응은 감소하는 것으로 생각된다. cathode에서 수소환원 반응 속도에 따라 전착층 내부의 수소함량이 변화하며, 수 소는 전착층 내부에서 기공 등을 형성하여 격자 변형을 유발 하기 때문에 내부응력 증가의 요인으로 생각된다.

\section{4. 결 론}

본 연구에서는 $\mathrm{Ni}-\mathrm{Mn}$ 전착층의 기계적 성질에 영향을 미치는 각종 공정조건의 영향을 검토하여 다음과 같은 결론 을 얻었다.

1) $\mathrm{Mn}\left(\mathrm{NH}_{2} \mathrm{SO}_{3}\right)_{2}$ 첨가량이 증가함에 따라 경도 및 내부응 
력은 증가하였으며, $\mathrm{Mn}$ 및 $\mathrm{S}$ 의 공석량도 증가하였다. $\mathrm{Mn}$ 이 $\mathrm{Ni}$ 전착층에 공석되면서 격자의 변형을 유발하고, 그 결과 경도와 내부응력이 상승하는 것으로 생각된다.

2) 전류밀도가 증가할 때 경도는 다소 감소하는 경향을 보 였으나, 감소량이 크지 않았다. 전류밀도가 증가하면 내 부응력은 상승하였는데, 전류밀도의 증가로 인하여 수 소환원반응 속도가 증가하며, 흡착된 수소가 격자변형 을 유발하여 내부응력을 증가시키는 것으로 판단된다.

3) 전착온도는 경도에 큰 영향을 주지 않았다. 그러나 전착 온도가 증가함에 따라 내부응력은 감소하였다. 온도가 상승함에 따라 cathode 쪽으로 높은 이온의 공급과 고온 에서의 핵생성 및 핵성장을 위한 활성화 이온 수의 증가 에 의해서 농도분극과 표면확산이 감소하는데, 이로 인 하여 수소환원반응이 억제되고 수소흡착이 감소하게 되 어 내부응력이 감소하는 것으로 생각된다.

\section{감사의 글}

본 연구는 인하대학교의 지원에 의하여 수행되었으며, 이
에 감사드린다.

또한, 본 연구는 지식경제부의 2012년도 기술혁신사업 인 '연주금형 장수명화를 위한 $\mathrm{Ni}-\mathrm{Mn}-\mathrm{B} 3$ 원합금도금 기 술개발' 과제의 일환으로 수행되었으며, 이에 감사드린다.

\section{References}

1. M. J. Kim, J. S. Kim, D. J. Kim, H. P Kim, and S. S. Hwang, Corros. Sci. Tech., 12, 185 (2013).

2. S. W. Kim and D. J. Kim, Corros. Sci. Tech., 12, 132 (2013).

3. D. Baudrand, Met. Finish., 7, 15 (1996).

4. C. L. White, J. H. Schneibel, and R. A. Padgett, Metall. Trans. A, 14A, 595 (1983).

5. J. N. Lee, S. W. Han, J. Korea Foundrymen's Society, 4, 62 (1984)

6. I. Kim, K. Kang, J. Lee, S. C. Kwon, M. Kim, and J. Y. Lee, J. Kor. Inst. Surf. Eng., 38, 21 (2005).

7. M. H. Seo, D. J. Kim, and J. S. Kim, Met. Mater. Int., 13, 365 (2007).

8. J. W. Dini and H. R. Johnson, Thin Solid Films, 54, 183 (1978). 